International Journal of Modern Anthropology

Int. J. Mod. Anthrop. 2019. Vol. 2, Issue 12, pp: 115 - 140

DOI: http://dx.doi.org/10.4314/ijma.v2i12.5

Available online at: www.ata.org.tn \& https://www.ajol.info/index.php/ijma

Research Report

\title{
Cart-ruts in Lanzarote (Canary Islands, Spain) and Malta: first evidence of dating supported by dated ceramics
}

\author{
Antonio Arnaiz-Villena ${ }^{1^{*}}$, Marcial Medina ${ }^{2}$, Adrian López-Nares $^{1}$, Julian \\ Rodriguez-Rodriguez ${ }^{2}$, Valentín Ruiz-del-Valle ${ }^{1}$ \\ ${ }^{1}$ Department of Immunology, University Complutense, School of Medicine, 28040 Madrid, Spain. ${ }^{2}$ Freelance \\ Lanzarote (Canary Islands) Archaeologists. * Corresponding author: Antonio Arnaiz-Villena. Departamento de \\ Inmunología, Facultad de Medicina, Universidad Complutense, Pabellón 5, planta 4. Avd. Complutense s/n, 28040, \\ Spain.E-mail:arnaizantonio@gmail.com ; aarnaiz@med.ucm.es ; Web page:http://chopo.pntic.mec.es/biolmol/
}

(Received 28 February 2019; Accepted 22 Mars 2019; Published 2 April 2019)

Abstract - Cart-ruts were first described throughout Malta Archipelago; they were defined as abundant prehistoric Bronze Age Man constructions carved in rock although more recently built cart-ruts may be possible. They consist of deep ruts, rails, tracks, grooves and channels that rarely are strictly parallel. Some of them are convergent or perpendicular to others and also they may abruptly change to curved lines. They are placed either in plains or hill slopes with a variable and high inclination, Cart-ruts purpose is not known, as there were no written images, myth or verbal record about what they were used for. A conjoint multiauthor European Union Project on cart-ruts has found no new conclusion except stressing where they had been found: Malta and Turkey (Bronze Age) and also in Africa (Tunisia, Libya and Egypt) and Spain, Italy, France, Switzerland, Greece, Portugal, England and Azerbaijan. Other authors have described them also in Azores Islands and in Lanzarote (Canary Islands, Spain). In the present paper, we show evidence that cart-ruts are found all over Lanzarote Island, mostly placed on hills (volcanoes) tops or slopes. This fact together with their limited length discards their use for transport vehicles. On the other hand, some Malta and Gozo Islands (Malta) pottery decoration dated on $5^{\text {th }}-4^{\text {th }}$ millennium BC has been found that may represent cart-ruts. This is the first objective and independent evidence indicating that cart-ruts may be dated by other prehistoric information. Also, cart-ruts social, ritual and religious importance is discussed, as they could be used for space and time measurements, including astronomical calculations.

Keywords: Malta, Gozo, Cart-ruts, Lanzarote, Fuerteventura, "Quesera"/Cheeseboard, Lunisolar calendar, Iberian writing, Guanche writing, Zonzamas, Canary Islands, Guanches, Majos, Archaeoastronomy, Goddess, Achano, Tunisia, Libya, Egypt, Turkey, Spain, Portugal, Azores, Azerbaijan, Ceramics.

Marcial Medina address: Arrecife, Lanzarote 3500, Islas Canarias, Spain. Email: marcialmedina53@gmail.com 


\section{Introduction}

The cart-ruts are prehistoric grooves hewn on the rock face of about ten to sixty centimeters deep and fifteen to twenty five centimeters wide, as observed in Malta Archipielago (Fig. 1). These are deep ruts, rails, tracks, grooves, channels left in Malta's limestone but in such numbers, variety and confusion that they leave more questions than answers. They are located all over the islands of Malta and Gozo. Cart-Ruts themselves are sunken grooves, ruts, tracks, rails found in rock. Channels are rarely running strictly in parallel. They follow approximate parallel convergent directions; some are perpendicular to others and finally others change to curved lines after a straight trajectory (Fig. 2 and Fig. 3).

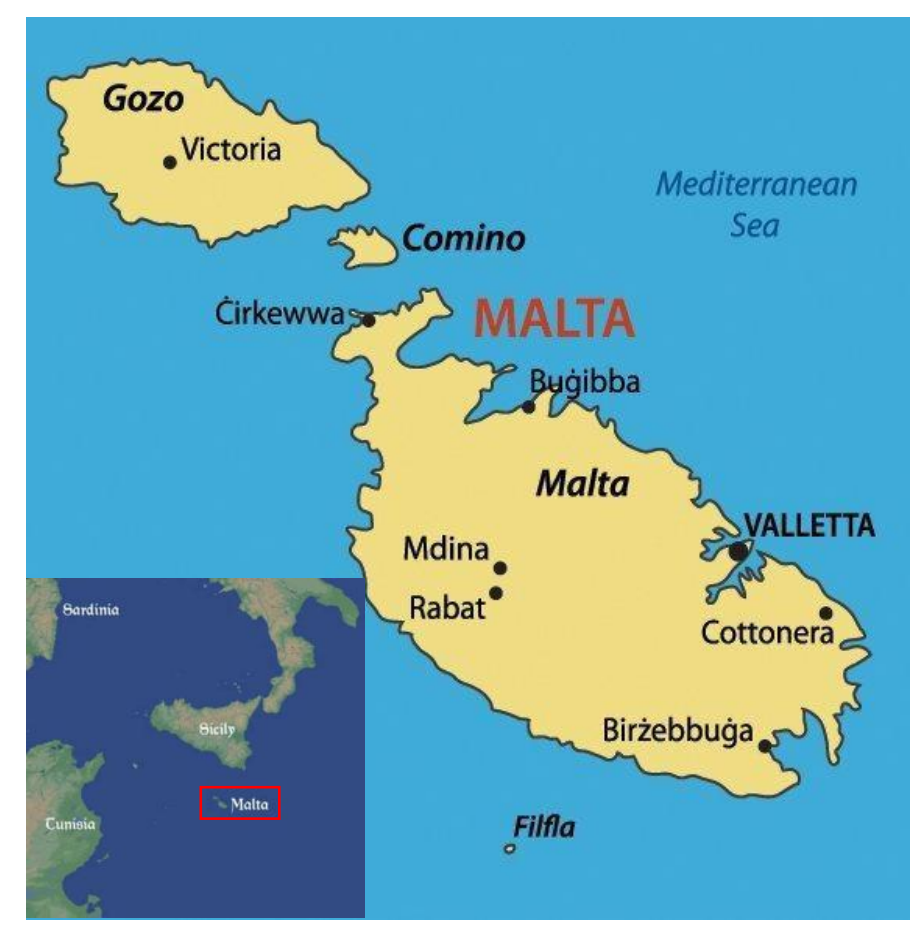

Fig. 1 Malta Archipelago

It is $95 \mathrm{Km}$ (59 miles) far from Sicily (Italy), $320 \mathrm{Km}$ (198 miles) far from Libyan Coast and 300 Km (186 miles) far from Tunisia Coast. 

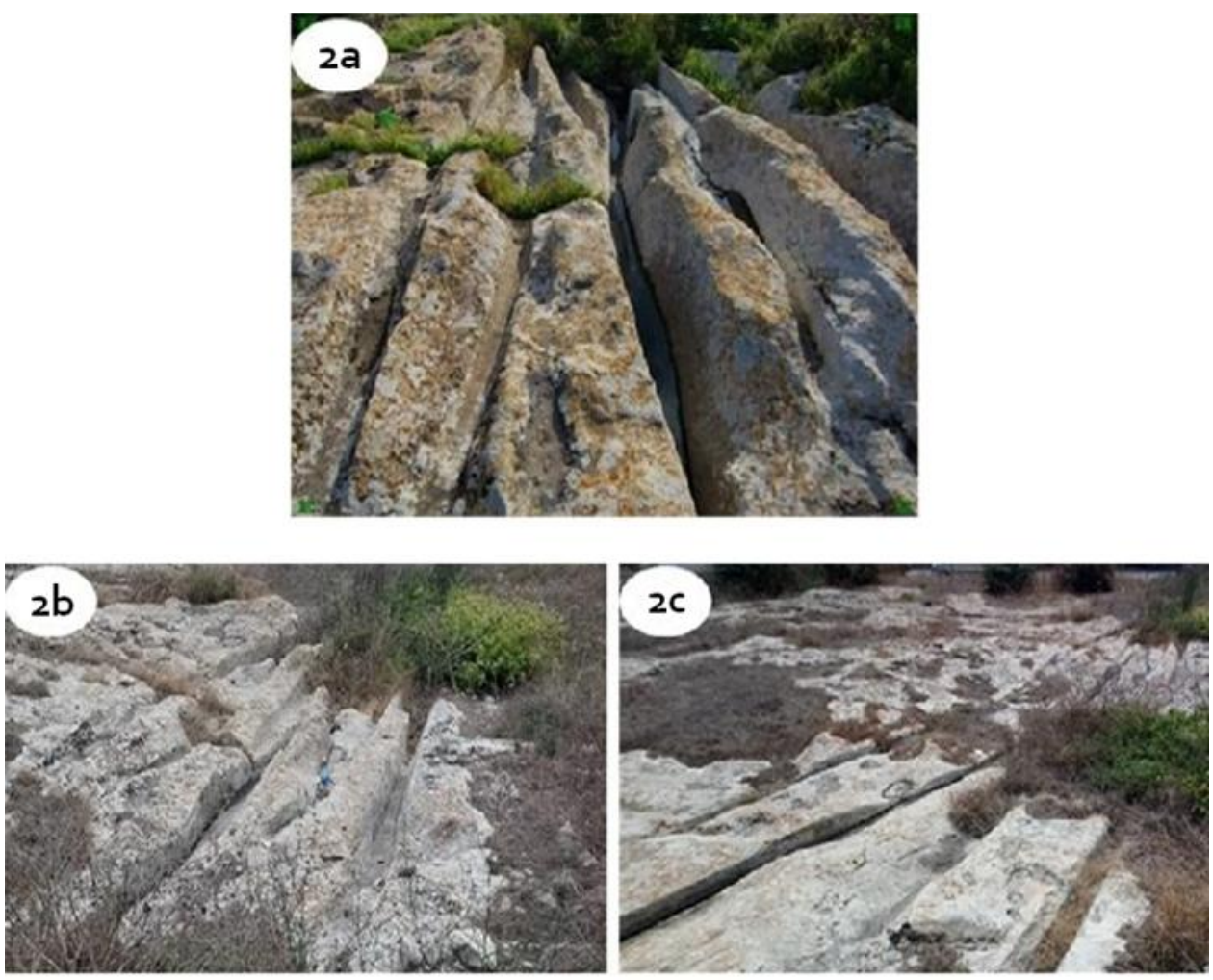

Fig. 2 Archaeological site of Tal-Mensija, San Gwann village, (Malta). $35.911^{\circ} \mathrm{N}, 14.478^{\circ} \mathrm{E}$. http://www.cartrutsmalta.com/

2a - Plain photograph. $2 \mathbf{b}-$ A North-East photograph of the cart-rut complex because ruts follow a South-West direction. $2 \mathrm{c}-$ A close up photograph of $2 \mathrm{~b}$.

The photographs were taken on summer noon day with full sun light which fades colors and also plants and dried bushes are exuberant because of the time of the year.

The purpose of cart-ruts is still an unsolved mystery, as there were no written, images (except evidences shown below in the present paper), myth or verbal record of what they were used for. Maltese historian, Abela (1647), described them and 'cart-ruts' were just as puzzling then as they are today. They have always been interpreted as tracks left by some form of vehicle, but the term 'cart-rut' may, in fact, be a misnomer when applied to all of the cuttings. Abela's clearly demonstrated that they belong to a more distant past, but time when they were made and who were peoples that fabricated them are matters that have puzzled archaeologists working in Malta until present. Bonanno states: 'The enigmatic cart-ruts are too obvious in the Maltese rocky landscape to be ignored in any work' (Bonanno 1993). They are in fact now widespread throughout the Archipelago and it is feasible that many of them have been destroyed. 
Dating cart-ruts is a difficult problem. Great antiquity is suggested by those examples that have underwent geological events; some have been cut short at cliff edges, others have been broken by fault lines and others go into sea (Trump 1998, 2002, 2008; Mifsud et al. 2000). Trump assigns their construction in Malta to Bronze Age, but building time maybe stratified depending on each studied site (Arnaiz-Villena et al. 2018). Cart-ruts are nowadays seen widespread throughout Malta and Gozo Islands.

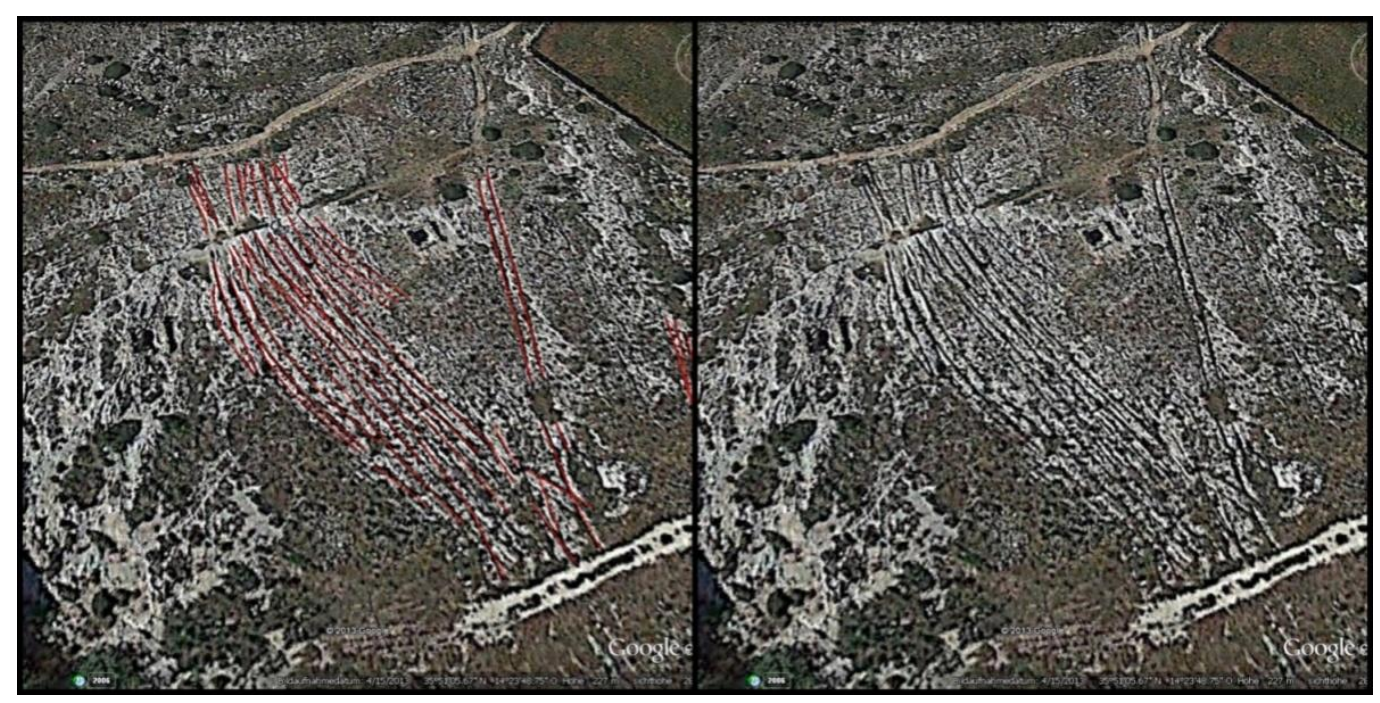

Fig. 3 Aerial view of Clapham Junction cart-ruts complex. South Malta Is. Malta. (Left photograph cart-ruts are marked by us in red color).

There are extensive studies of many of the Malta cart-rut sites which are nowadays identified and some of them are studied in deep (Trump 2002, 2008; Bonnici 2017). They have been constructed by man and not by Nature because of their intentional skewing and steps and also their sometimes strict parallelism, convergence or curve perfection in many cases (Trump 2008). They started to be built at Malta around Bronze Age or before at Temples Age (Trump 2002, 2008; Bonnici 2007) and they may have been continued to be built in later periods (Trump 2002, 2008; Bonnici 2007). As started above, their function is debated: most of them are useless as rail roads for any kind of transport; therefore, this "cart-ruts" name is misleading. At present, scholars only think practical and present day terms of usefulness. However, the problem of the many cart-ruts use and purpose in Malta is not more important than the problem 
of explaining why so many megalithic temples were built in Malta since $5^{\text {th }}$ millennium $\mathrm{BC}$, many of them with precise astronomical intentionality. By homology with temples, one could not discard that cart-ruts are also necessary for establishing time and also astronomical/geographical directions or even being used for a religious purpose. It is widely accepted that both Malta megalithic temples and cart-ruts belong to Megalithic Culture (Trump 2002, 2008; Bonnici 2007; Bonanno 2017) and that some of them may have been built in more recent times.

Cart-ruts exist in other parts of the World including Atlantic Islands (Azores Islands, Portugal) and Lanzarote (Canary Islands Fig. 4) (Arnaiz-Villena et al. 2018). These two places were not included in the European Community Research Project led by Prof. Bonnici (2009) which has widely studied cart-ruts in Mediterranean area and different authors explain their discoveries and views. Cart-ruts have been found in several countries: Spain, Italy, France, Switzerland, Greece, Portugal, England, North Africa (Egypt, Dougga in Tunisia and Cyrene in Libya), Turkey and Azerbaijan. However this multi-author study (Bonnici 2007) is missing cart-ruts extant in the Atlantic Ocean, i.e.: Lanzarote Arnaiz-Villena et al. 2018 and (present paper) and Azores Islands (Ribeiro et al. 2015, 2017; Rodrigues et al. 2015).

In the present paper, we aim:

1) To show cart-ruts discovered in Fuerteventura and Lanzarote (Canary Islands, Spain);

2) To offer a Malta cart-ruts independent ancient dating by comparing them with Maltese dated prehistoric pottery decoration which could represent cart-ruts, and 3) To compare this cultural trait (cart-ruts) of prehistoric Maltese and Canary Islands together with other prehistoric Canarians traits.

On the other hand, volcanic rock-carved strips and hollows from Lanzarote (Fig. 5) lunisolar calendar were found apparently very similar to many Malta cart-ruts convergences (Figs 2a and 2b). This lunisolar calendar was described by us and is represented in a Lanzarote (Canary Islands, Spain) structure: this monument was named "Quesera"/Cheeseboard at Zonzamas archaeological site close to capital Arrecife (Fig. 5) Sun calendar (Medina \& Arnaiz-Villena, 2018a, 2018b). We also found what could be "Quesera"/Cheeseboard calendars in Malta and clear cart-ruts in Lanzarote (Arnaiz-Villena et al. 2018). 


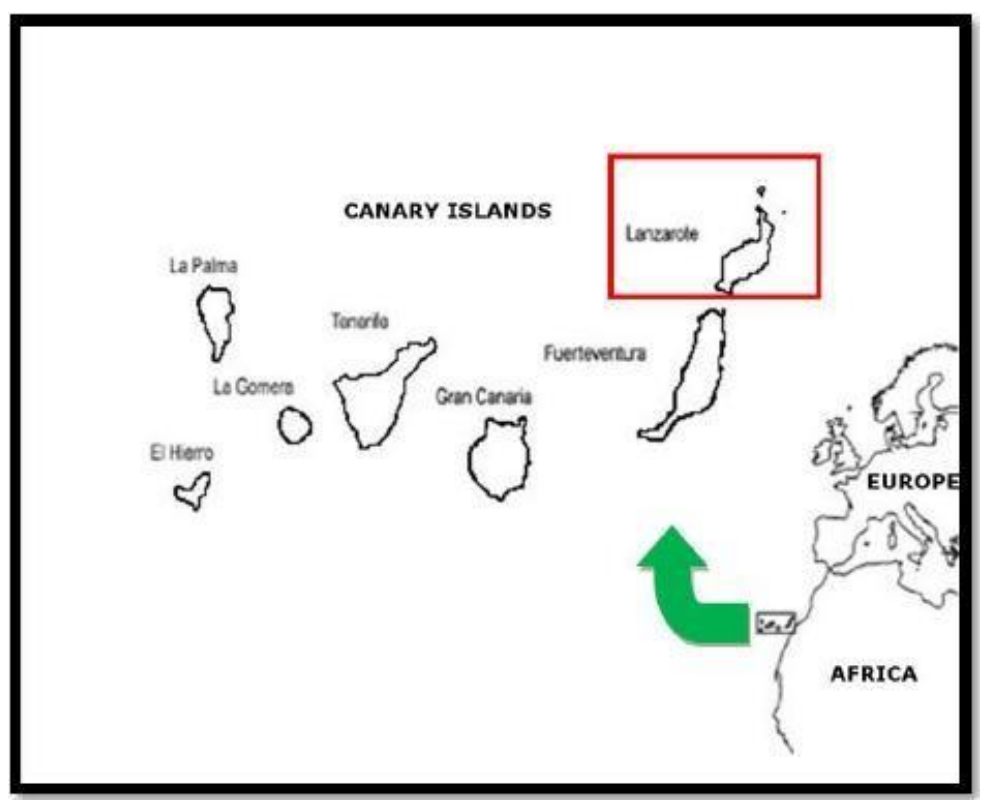

Fig. 4 Map of Canary Islands with islands names and the Atlantic coast lines of Europe and North West Africa.

Lanzarote Is. is $125 \mathrm{~km}$ (78 miles) apart off African Coast. Interest is on a prehistoric monument at Lanzarote (marked inside a red square): Fuerteventura Island is placed below Lanzarote. These are volcanic islands (25-15 million years old).

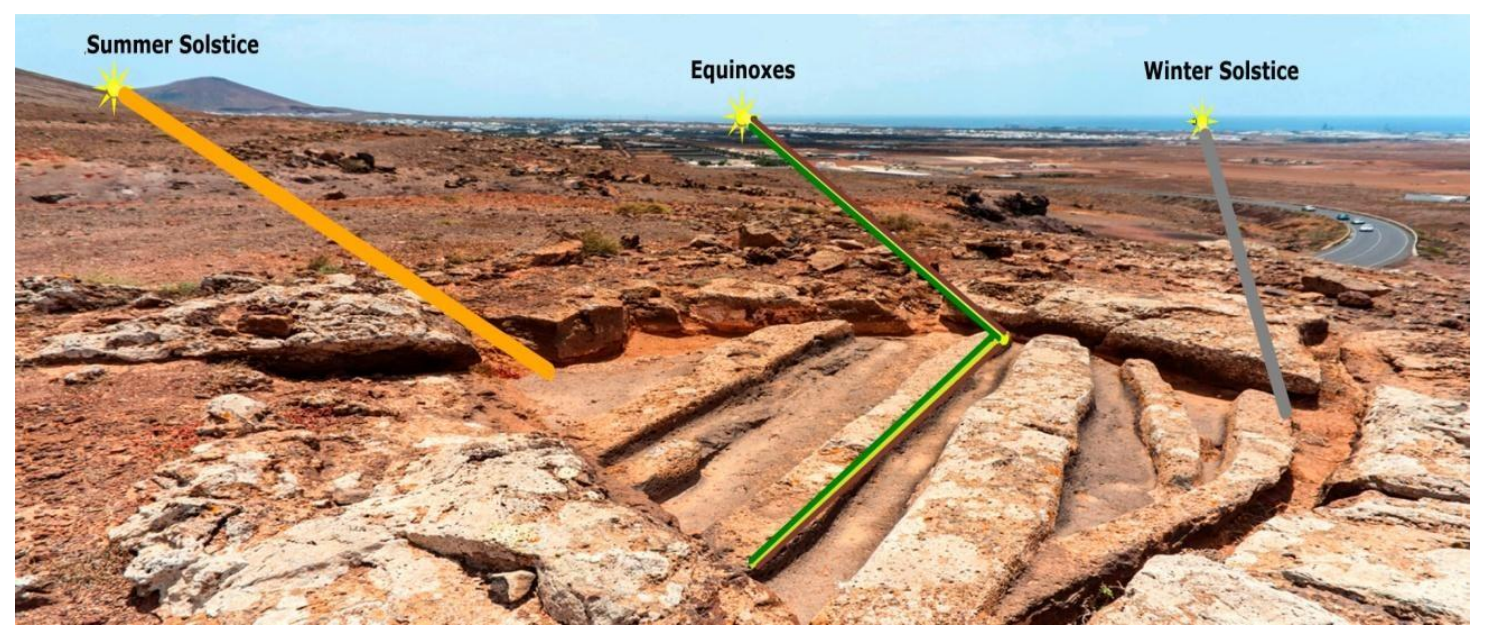

Fig. 5 Sunrise at Summer Solstices, Autumn/Spring Equinoxes and Winter Solstice from a "Quesera" observer (left to right). Photography from "Quesera"/Cheeseboard of Zonzamas

Left: Sun rises (2014 AD) between Maneje and Tahiche mountains at Summer Solstice (orange line). It is possible that if "Quesera" is ancient enough, an observer from this point might have seen Sun rising at Tahiche mountain slope or vertex in Antiquity because Ecliptic obliquity is diminishing about 0.47 arch seconds per year at present times, (Magli, 2016). Middle: Sun rises at middle sea horizon, both at Autumn and Spring Equinoxes (green line).

Right: Sun rises at right sea horizon at Winter Solstice (grey line). Sunrises complete a yearly azimuth arch between about $62^{\circ}$ and $117^{\circ}$ degrees going from June 21 st to December 21 st and back. 


\section{Materials and Methods}

\section{Malta}

Malta field work was carried out with a compass/ inclinometer NS1620 (SAC Electronics, Sutton, Nottinghamshire, UK). At least three different measurements were taken for each value. Also, a Sony Camera Cybershot 14.1 Megapixels Carl-Zeiss lens Vario-Tessar was used for photograph work. In addition, Android software Ulysse Gizmo was also employed as compass/inclinometer to obtain azimuth, geographical directions and longitude/latitude. Its software was calibrated each time after one single use and several measures were taken in three different times; also reverse direction measurements were taken for assessing data. Values obtained by SAC compass/inclinometer were coincidental with those obtained by Ulysse Gizmo software in a Sony Xperia G3112 cellular phone.

\section{Lanzarote}

\section{Study}

Marcial Medina was born in Lanzarote. He is a freelance archaeologist who has searched together with a group of freelance and other archaeologists, every Lanzarote's corner and has discovered many ancient rock engravings, cart-ruts and other ceramic and archaeological tools. $\mathrm{He}$ is a sailor and had knowledge of astronomic measurements. Thus, he measured sunrise azimuth and altitude every day during a two years period (2014-2015) from the "Quesera"/Cheeseboard de Zonzamas elevation (162 meters, 531 feet above sea level) placed at $29.0005702^{\circ}$ North latitude and $1.5677934^{\circ}$ West longitude.

\section{Methods}

SPSMAP 60c color map Navigator was used for local coordinate assessment (Garmin International, Kansas, and USA). Suunto Tandem/360PC/360R DG compass and inclinometer (Turku, Finland) was used to astronomical records (Medina \& ArnaizVillena 2018a) and a computer program calculated other parameters (SunEarthTools.com, online program). Other instruments were used for reassessing measurements: above mentioned SPSMAP navigator and binoculars 7x50 Estancos 
Anti-Impactos with Plastimo Compass (Sea Binoculars, Plastino USA Inc, Wilmington, Delaware, USA).

\section{Results}

\section{Malta}

\section{Cart-ruts}

Malta Cart-ruts sites in Malta could have apparent similarities with Lanzarote "Quesera"/Cheeseboard; although they need further study. We have examined three of them. First one was placed at San Gwan City center (Fig. 2) surrounded by modern buildings which had destroyed a great part of cart-ruts. In fact, removing bushes and grasses it was possible to distinguish 6 rock carved channels and 6 strips (Fig. 2). Our construction view may not correspond to the initial builder aim, however, twelve rock elements (prominent and hollow strips), like in Lanzarote "Quesera"/Cheeseboard were recorded; this bunch of cart-ruts is deteriorated and also some of the strips go further up (about 30 meters - 98 feet) as far as they became discontinuous, probably because of construction of modern houses and destruction (Arnaiz-Villena et al. 2018).

Second site was placed at Ta Cenc area on the southern part of Gozo Is. close to cliffs and to the City of Sannat. Again, a structure similar to "Quesera"/Cheeseboard was observed in this case (Fig. 6a) and 6 hollows and 6 prominent strips could be traced; this figure is also similar to the lunisolar prehistoric calendar found in Lanzarote (Fig. 6b "Quesera"/Cheeseboard) (Arnaiz-Villena et al. 2018). This structure that was more isolated than the first one studied at San Gwan City center (Fig. 2).

A third cart-rut site was studied at San Pawl tat-Targa because it also had a convergent stem of cart-ruts that had been cut because a modern road has been built (from Salina town to Naxxar town), see aerial photograph of part of the complex in Fig. 7 (Arnaiz-Villena et al. 2018) The cart-rut stem is of a doubtful interpretation; it might be a "Quesera"/Cheeseboard construction or not, because it is mostly destroyed (see Arnaiz-Villena et al. 2018). 

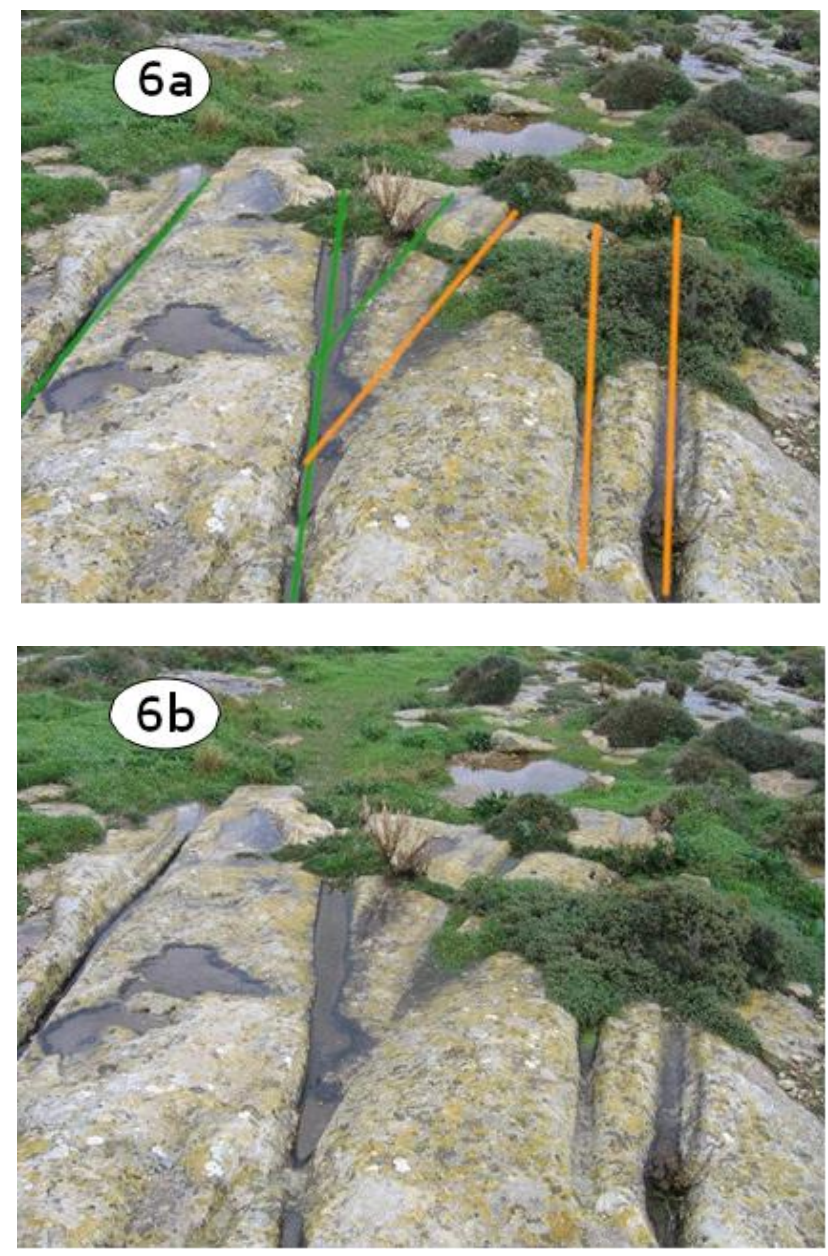

Fig. 6 Archaeological site of Ta Cenc, Sannat Town, close to cliffs (Gozo Is., Malta). $36.017^{\circ} \mathrm{N}, 14.259^{\circ} \mathrm{E}-6 a$ - Underlined carved strips in order to make it clear that it is a construction similar to Lanzarote "Quesera" / Cheeseboard rock prehistory calendar.6b-Plain photograph.

This site showed a big water ancient cistern entrance and a channel that cuts a cart-rut for facilitating water flow into the cistern; it was done for diverting water directly into big cistern (Fig. 7). This may indicate a function for some of the cart-ruts, consisting of picking up water. This has already been suggested and discarded by most authors (Trump 2002, 2008; Bonnici 2007) because these cistern structures have not been found in most cart-ruts places. Notwithstanding, they might be found if looking for them. In fact this cistern is very similar to that found close to Temples of Mnajdra and Hagar Qim (3,000-2,500, years BC), see images in (Arnaiz-Villena et al. 2018). 


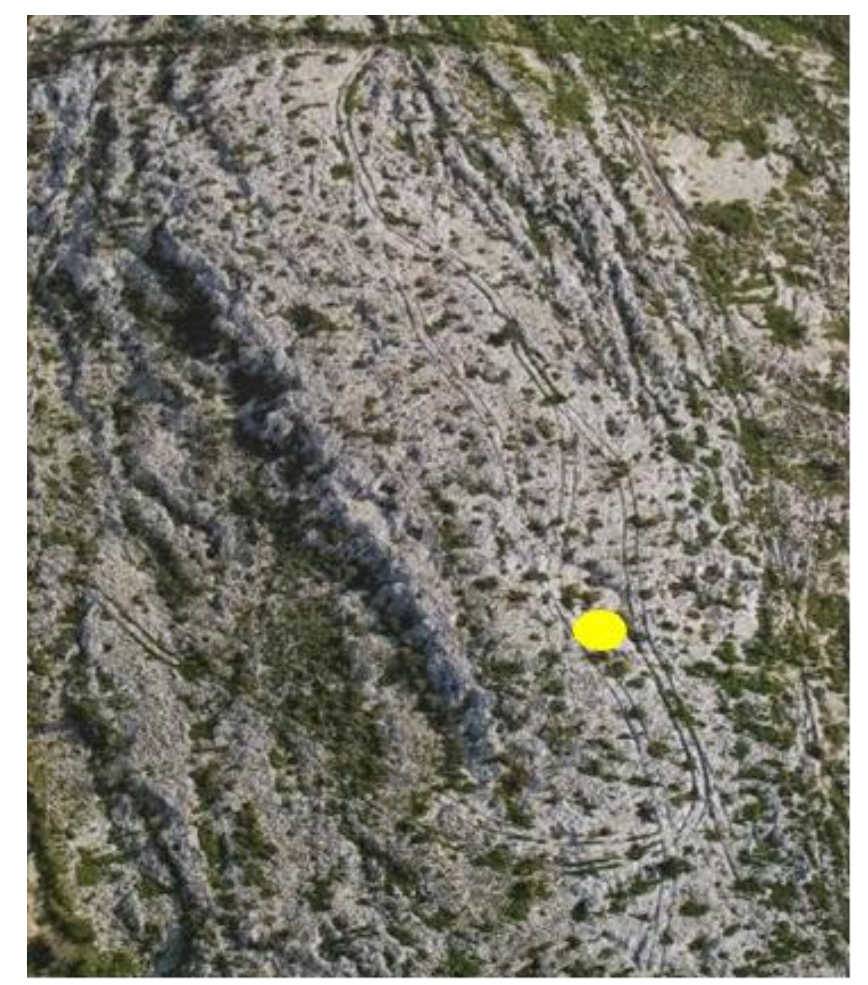

Fig. 7 Aerial view of San Pawl tat-Targa cart-ruts complex

Plain forms a $43^{\circ}$ inclination with horizontal. It is a hill slope. Yellow dot: place where an apparent site to collect water in a big cistern is found cut into rock. Probably it was a prehistoric water tank, like others already found and related to Malta temples of Mnajdra and Haggar Qim.

\section{Ceramics}

No representation of these Malta cart-ruts has been described either by a wide group of international archaeologists in a European Project (Bonnici 2007) or other cart-ruts researchers (Abela 1984; Trump 1998, 2002, 2008; Bonanno 2017). However, a detailed look of extant and dated ceramics shows that some pottery could have cart-ruts drawings. At Gozo museum (Victoria, Gozo Island, Malta), pottery may be observed that could bear cart-ruts representations. Fig. 8 is a photograph of a medium sized pot that is exposed and dated at about 3,150-2,000 years BC and was found at Ggantija North Cave in Gozo Is. Putative cart-ruts are underlined in red by us in Fig. 8. A Pearshaped jar is also shown in the same Gozo museum (Fig. 9). It was found at Xaghra City (Gozo Is.); jar shows lines similar to nowadays extant Malta cart-ruts. Assigned data is about 4,100-3,700 years BC Fig. 9 shows also this same jar decoration marked in red by us. 


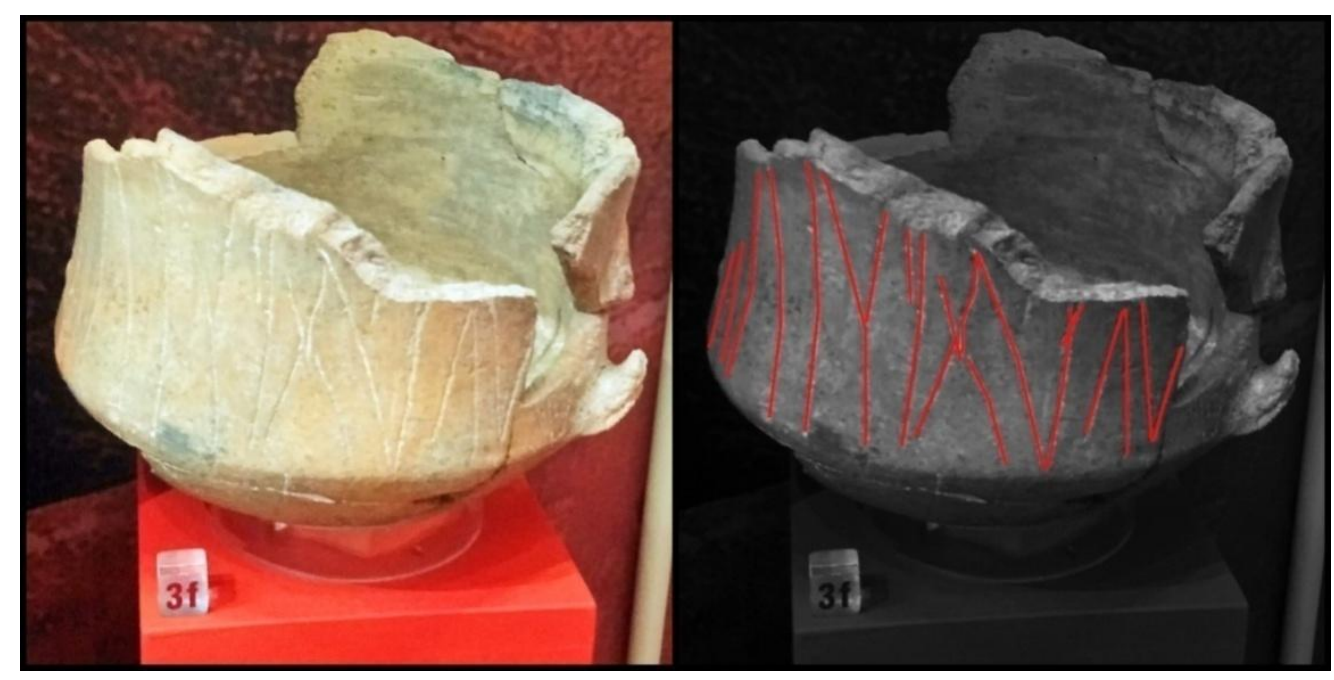

Fig. 8 Medium-sized pot (3,150-2,500 BC). Ggantija North Cave. Gozo Is. (Victoria Museum). Malta.

Left: Plain photograph. Right: Photograph with decoration marked in red by us

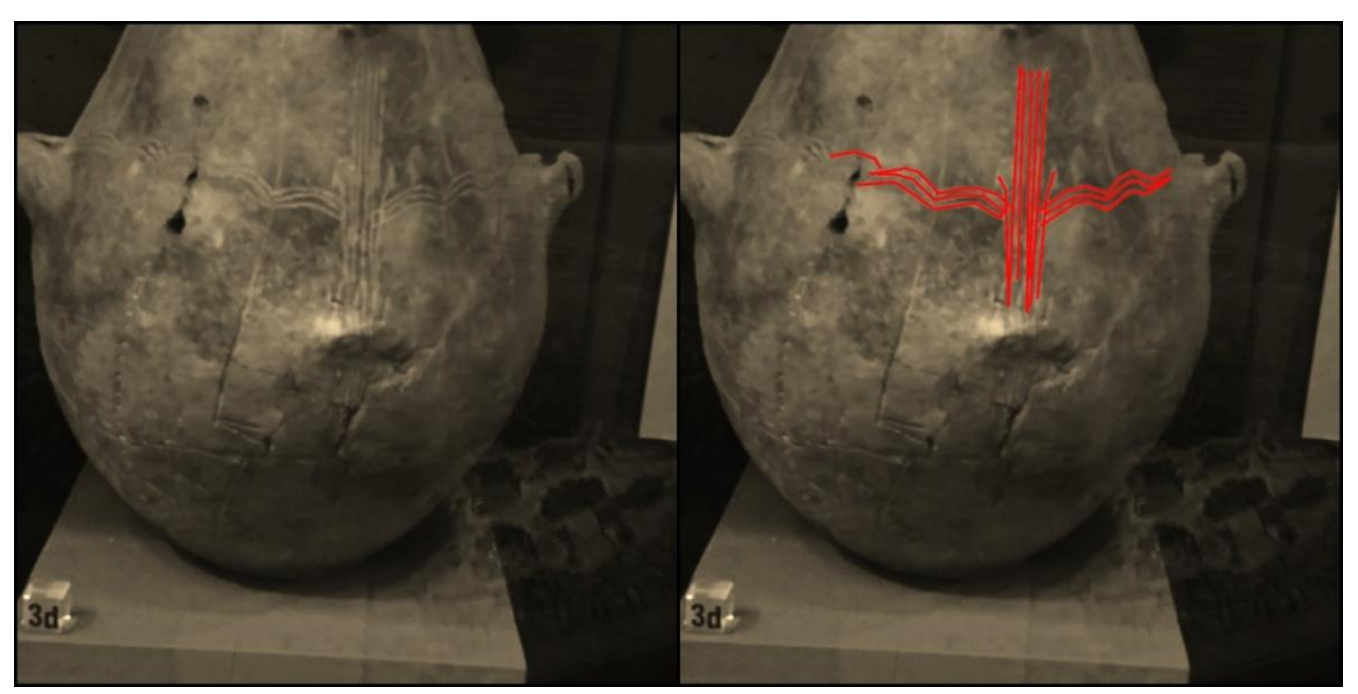

Fig. 9 Pear-shaped jar (4,100-3,700 BC) Mikiel Farrugia Street, Xaghra.Gozo Is. (Victoria Museum). Malta.

Left: Plain photograph. Right: Photograph with decoration marked in red by us.

In addition, ceramics shown at main Malta Is. Archaeological Museum at La Valletta has also been examined. Many fragments may represent cart-ruts; however we have only shown some of them in Figs 10, 11 and 12.A small fragment of ceramics coming from Ta Hagrat Temples is dated about 3,700 BC. Fig. 11 shows several small other fragments which may have also been decorated with cart-ruts; they are dated about 4,100 years BC and come from Mggar and Skorba Temples. Fig.12. shows a pear 
shaped jar which may be decorated with a schematic human figure and also with several possible cart-ruts.

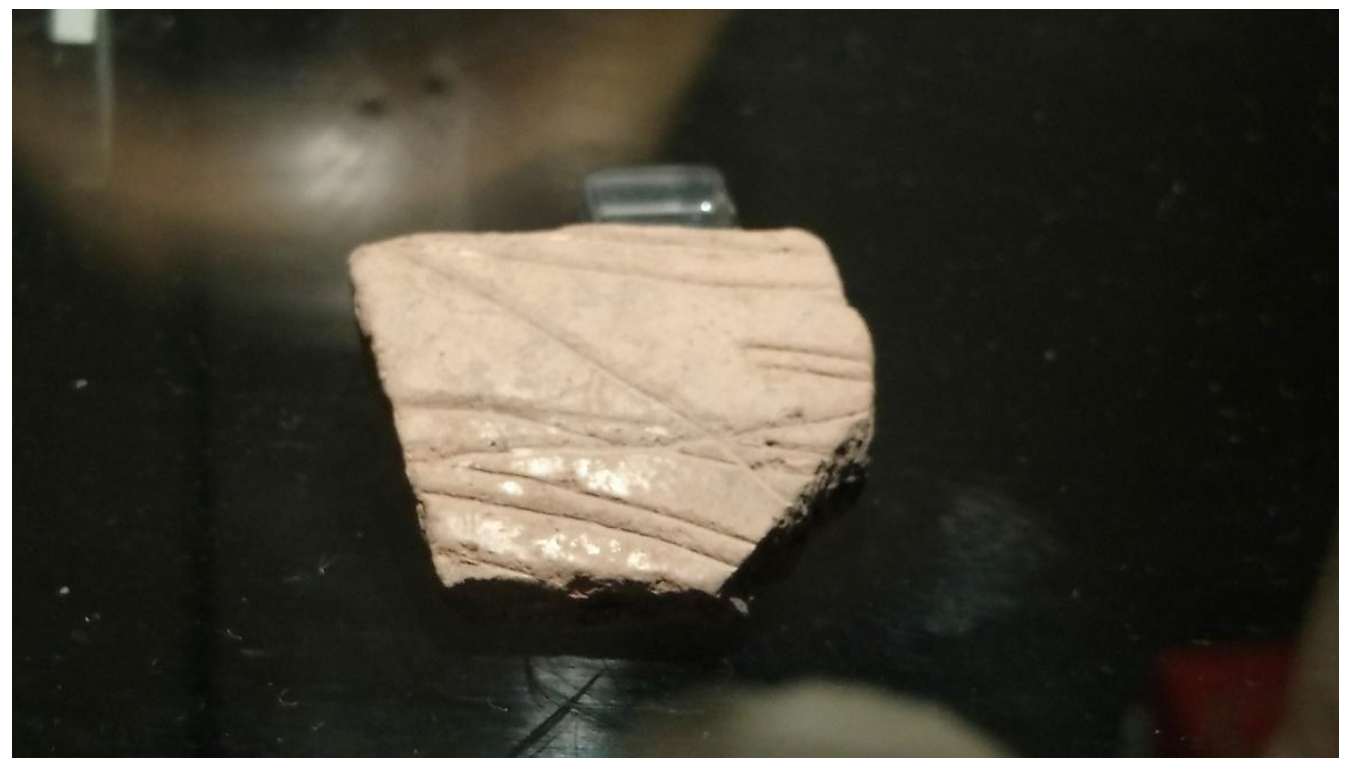

Fig. 10 From Ta Hagrat Temples in Mggar-Malta (3,700 BC). La Valletta Museum

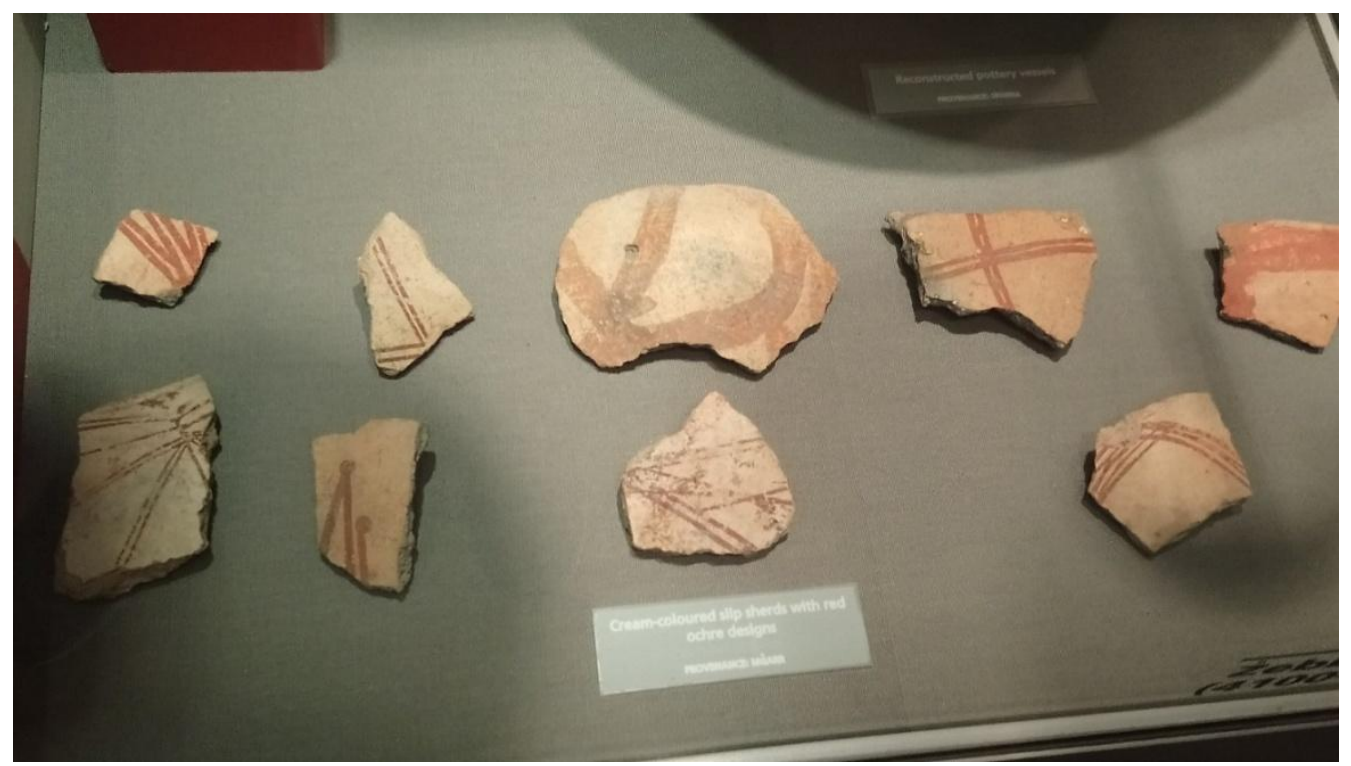

Fig. 11 From Maggar and Skorba Temples phase-Malta (4,100 BC). La Valletta Museum 


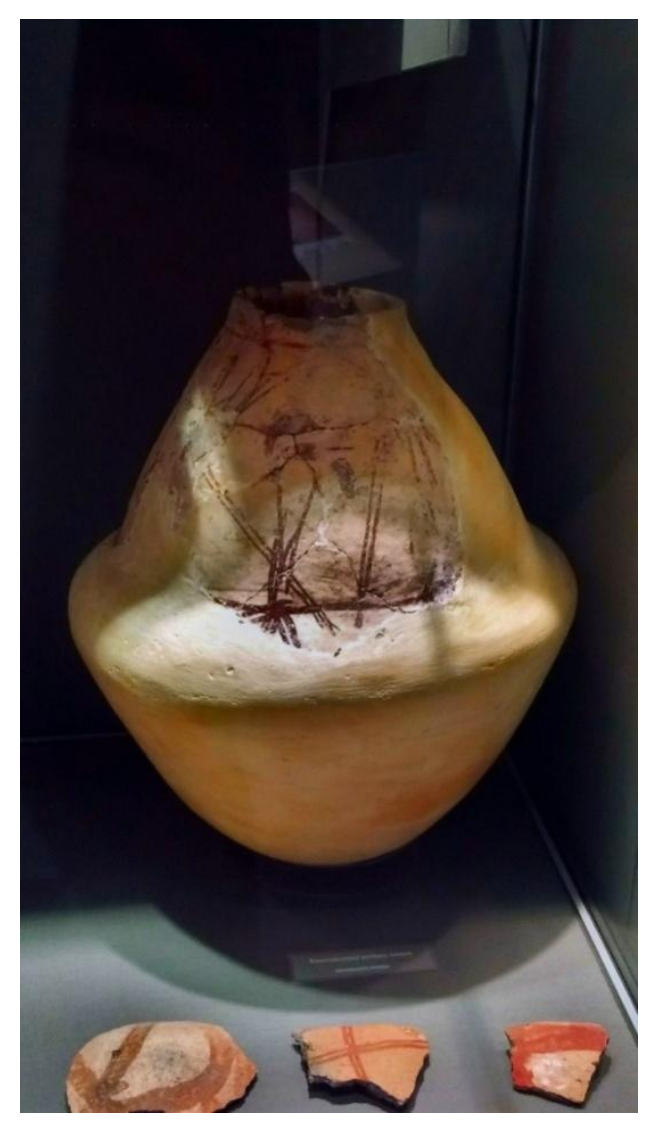

Fig. 12 Pear-shaped pot.

From Skorba Temple (4,100 BC). La Valletta Museum

\section{Lanzarote}

\section{Cart-ruts}

Cart-ruts have also been found in several locations at Lanzarote Is. A wide survey throughout the last twenty years has been carried out in Lanzarote by Medina and components of free-lance Lanzarote archaeologists detailed in authorship and in acknowledgements sections. One of the cart-ruts complexes has been observed and described in Tenezera or Tenesera Mountain. In the same Tenezera Mountain, Lybic Berber and "Latin" or Ibero-Guancherock inscriptions have been found. (Arnaiz-Villena \& Alonso-García 2001;

https://commons.wikimedia.org/wiki/File:Iberian-Guanche_inscriptions.pdf). Cart-ruts are placed and depicted in Figs. 13, 14, 15, 16, 17, 18, 19, and 20. 


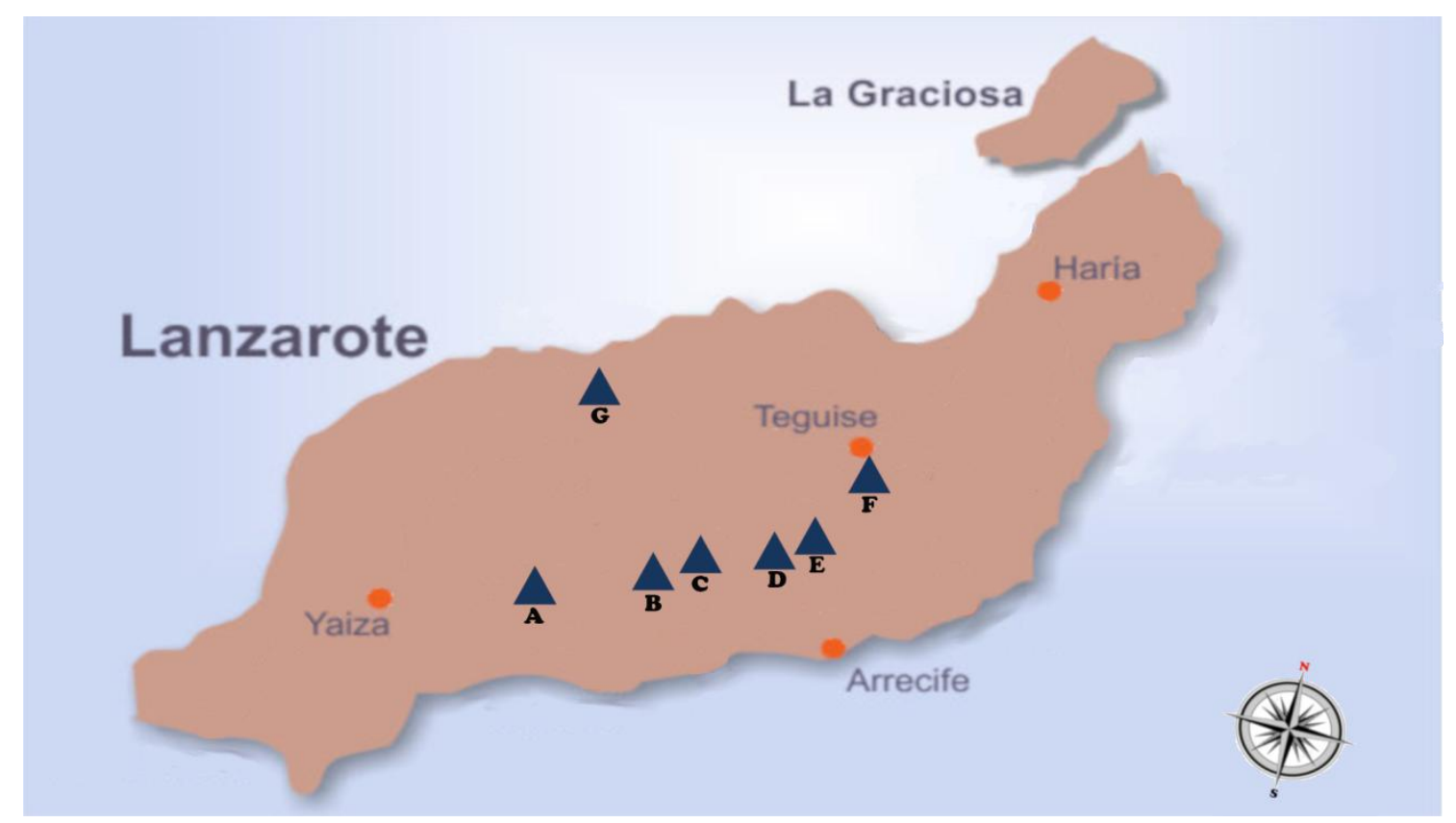

Fig. 13 LANZAROTE CART-RUTS SITES

Cities: Yaiza: $28^{\circ} 57^{\prime} 18^{\prime \prime} \mathrm{N} 13^{\circ} 46^{\prime} 00^{\prime \prime} \mathrm{W}$, Arrecife: $28^{\circ} 57^{\prime} 45^{\prime \prime} \mathrm{N} 13^{\circ} 33^{\prime} 02^{\prime \prime} \mathrm{W}$, Teguise: $29^{\circ} 03^{\prime} 40^{\prime \prime} \mathrm{N} \mathrm{13} 33^{\circ} 35^{\prime \prime} \mathrm{W}$, Haría: $29^{\circ} 08^{\prime} 49^{\prime \prime} \mathrm{N} 13^{\circ} 29^{\prime} 53^{\prime \prime} \mathrm{W}$.

Mountains: AMt. Guardilama: $28^{\circ} 57^{\prime} 42.0^{\prime \prime} \mathrm{N} 13^{\circ} 42^{\prime} 24.0^{\prime \prime} \mathrm{W}$, BMt. Montaña Blanca: $28^{\circ} 58^{\prime} 42.1^{\prime \prime} \mathrm{N} 13^{\circ} 38^{\prime} 27.8^{\prime \prime W}$, CMt. Guatisea: $28^{\circ} 59^{\prime} 31.1^{\prime \prime N} 13^{\circ} 37^{\prime} 50.0^{\prime \prime W}$, DMt. Mina:

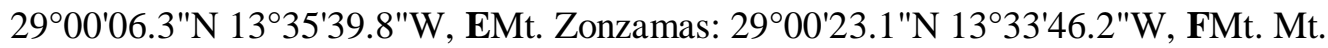

Guanapay (Castillo de Santa Barbara): 2903'28.6"N 1333'00.7"W, GMt. Tenezara: $29^{\circ} 04^{\prime} 01.0^{\prime \prime} \mathrm{N} 13^{\circ} 42^{\prime} 24.3^{\prime \prime} \mathrm{W}$.

Fig. 13 shows places where cart-ruts have been found in Lanzarote Is. They are all recorded on hills which are volcano slopes or tops on the eastern part of the island except in the case of Tenezara which is placed on West. These volcano-mountains sites have not been covered by historic Lanzarote eruptions (1730 AD, 1824 AD). 


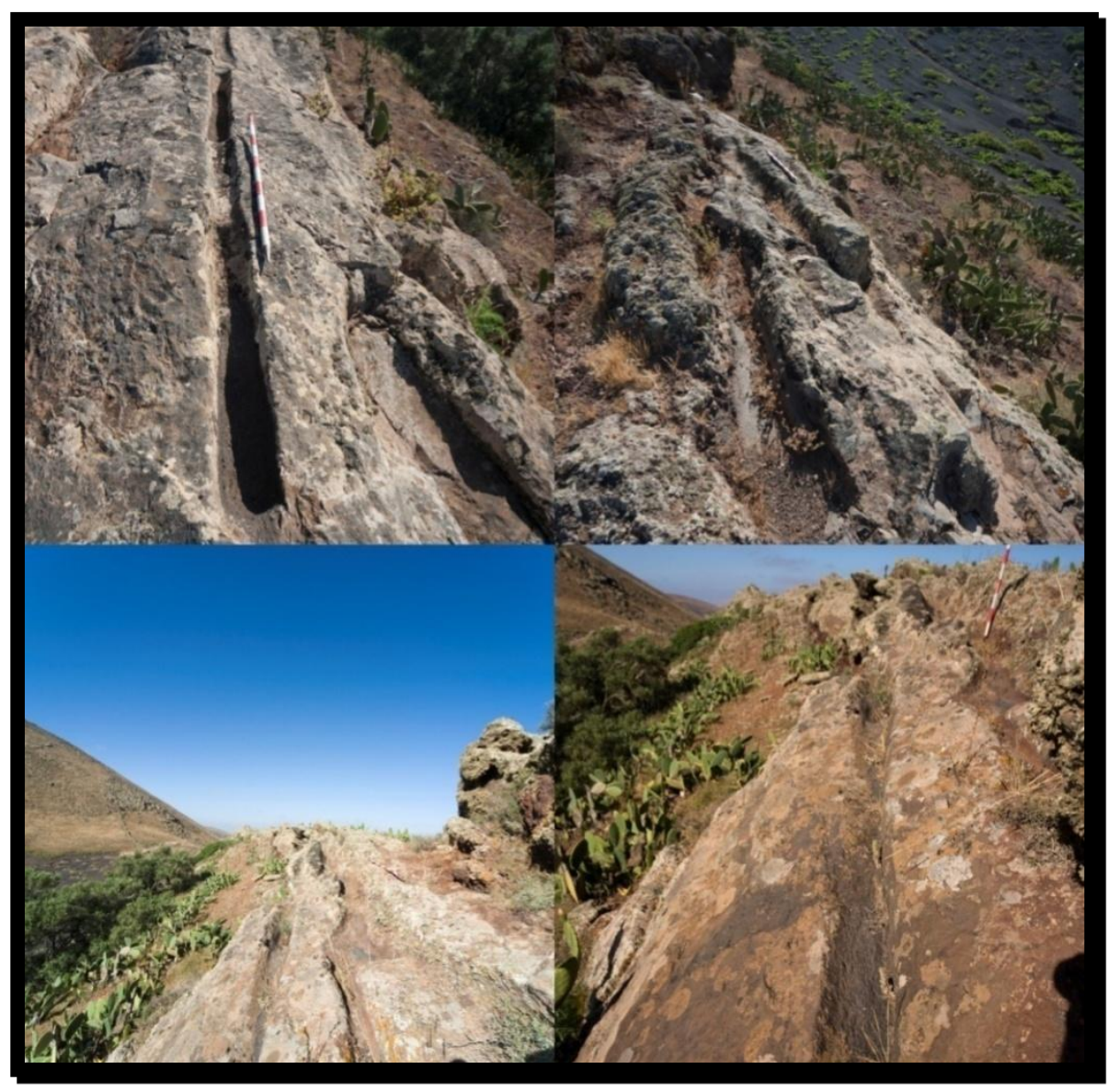

Fig. 14 (A in Fig. 13) Lanzarote Mt. Guardilama: 2857'42.0"N 1342'24.0"W

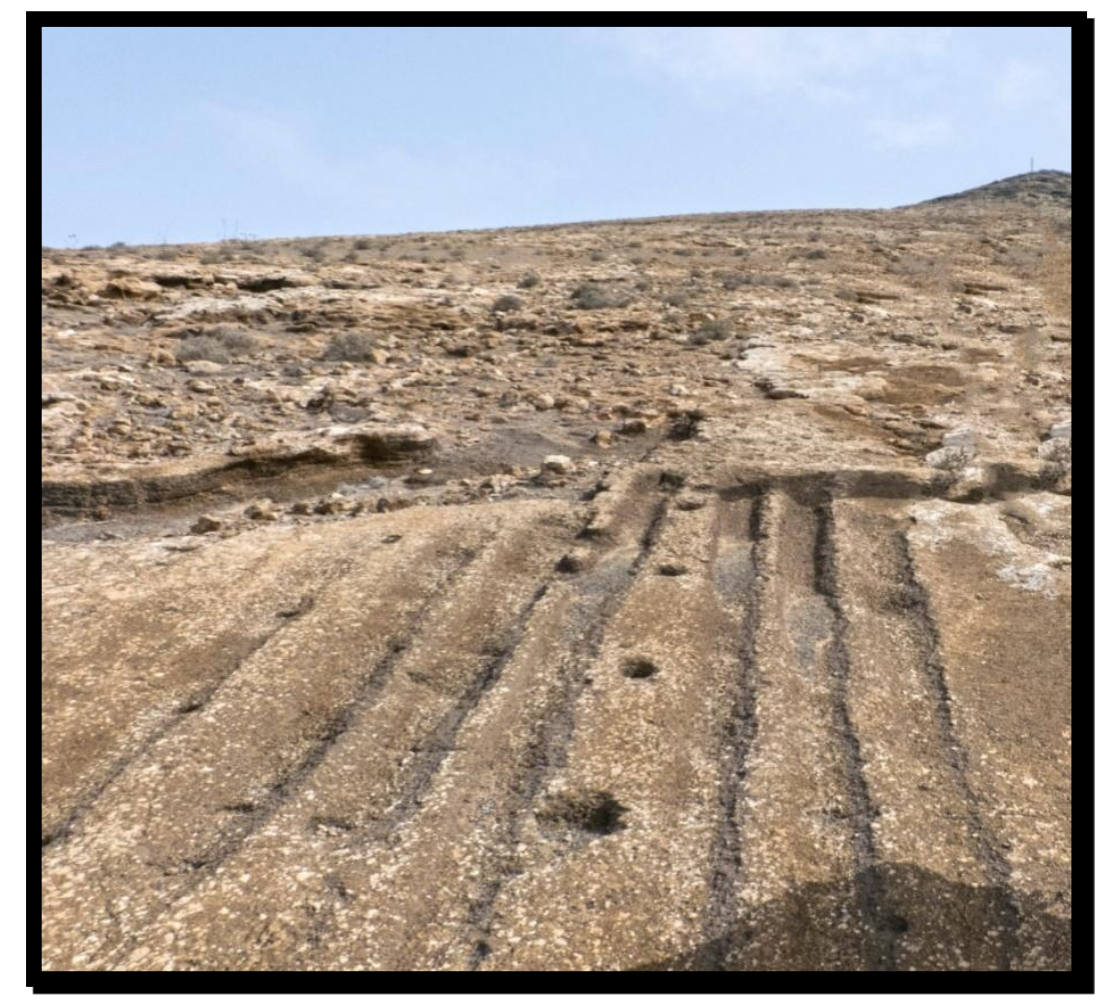

Fig. 15 (B in Fig. 13) Lanzarote Mt. Montaña Blanca: 2858'42.1"N 1338'27.8"W 


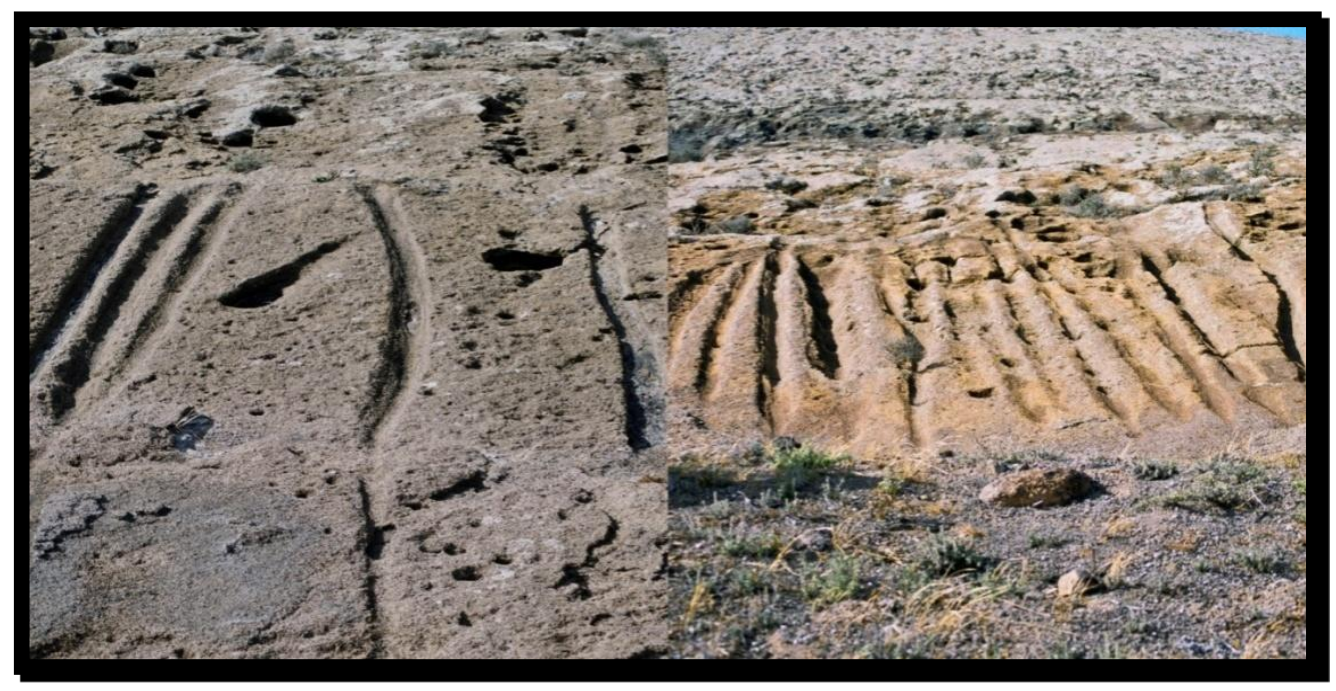

Fig.16. (C in Fig. 13) Lanzarote Mt. Guatisea: 2859'31.1"N 13³7'50.0"W

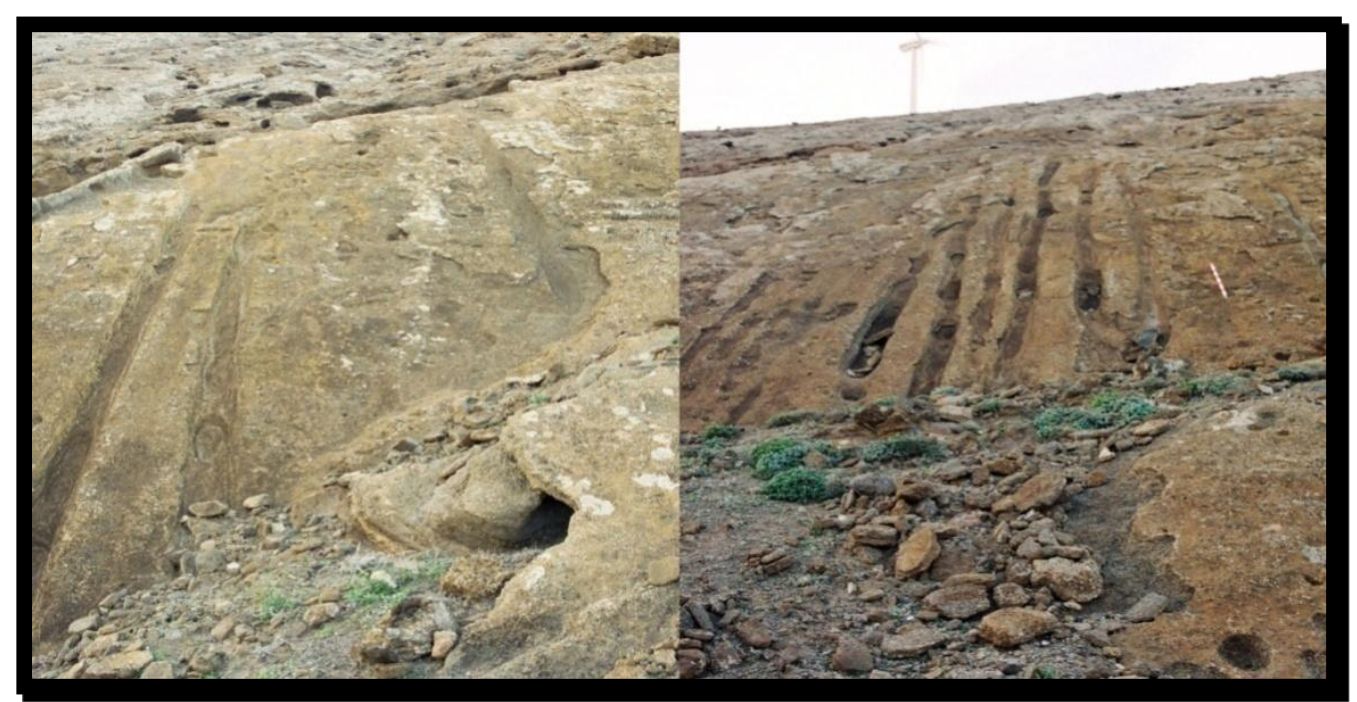

Fig. 17 (D in Fig. 13) Lanzarote Mt. Mina: 2900'06.3"N 13³5'39.8"W

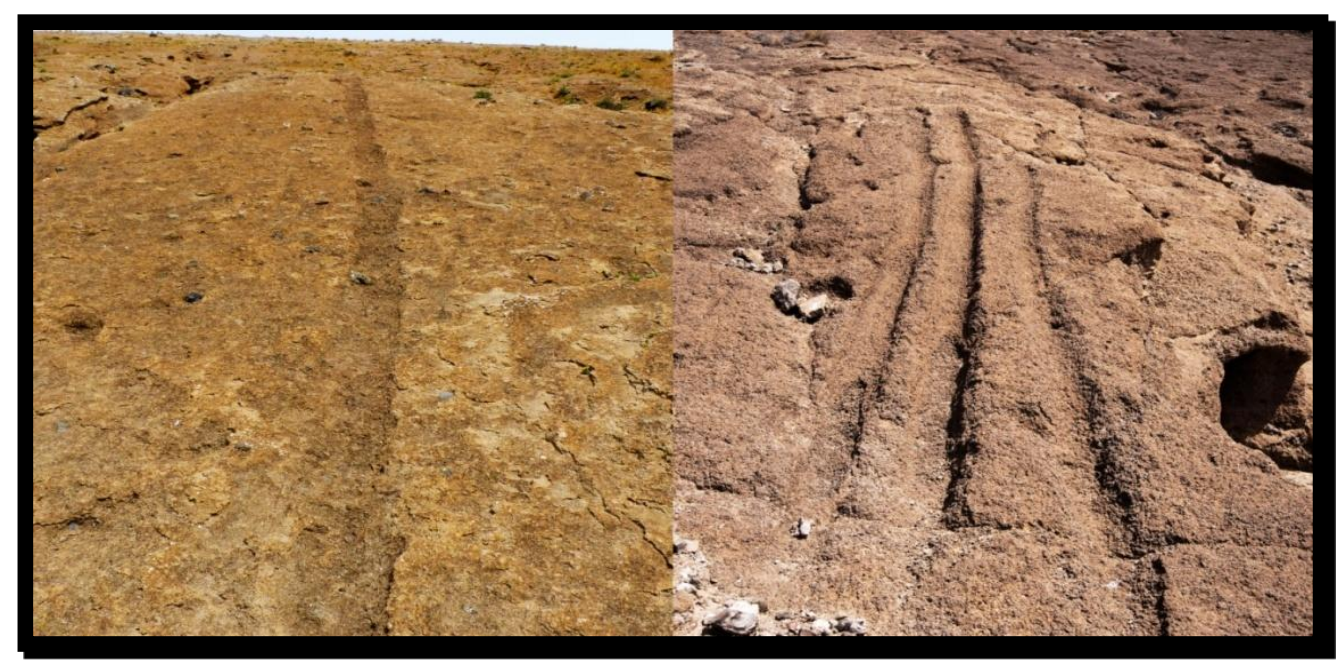

Fig. 18 (E in Fig. 13) Lanzarote Mt. Zonzamas: 2900'23.1"N 133' $46.2^{\prime \prime} \mathrm{W}$ 


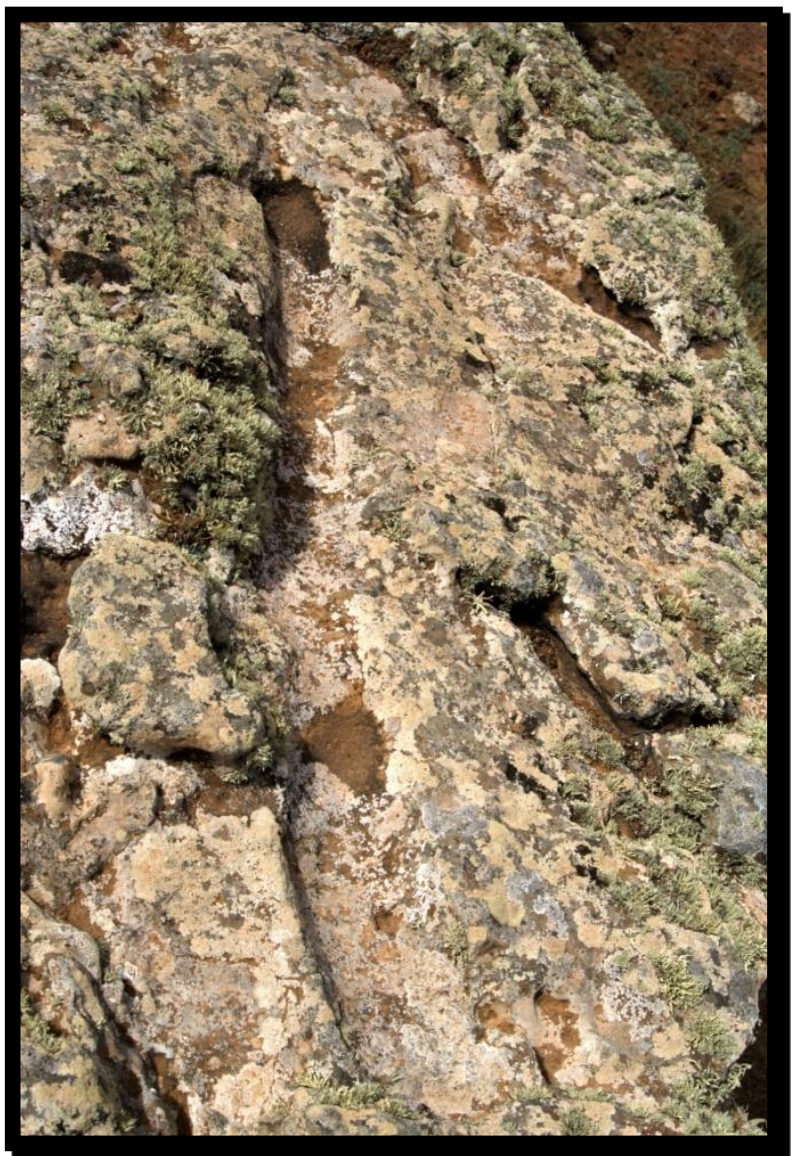

Fig. 19 (F in Fig. 13) Lanzarote Mt. Guanapay (Castillo de Santa Barbara): $29^{\circ} 03^{\prime} 28.6^{\prime \prime} \mathrm{N} 13^{\circ} 33^{\prime} 00.7^{\prime \prime} \mathrm{W}$

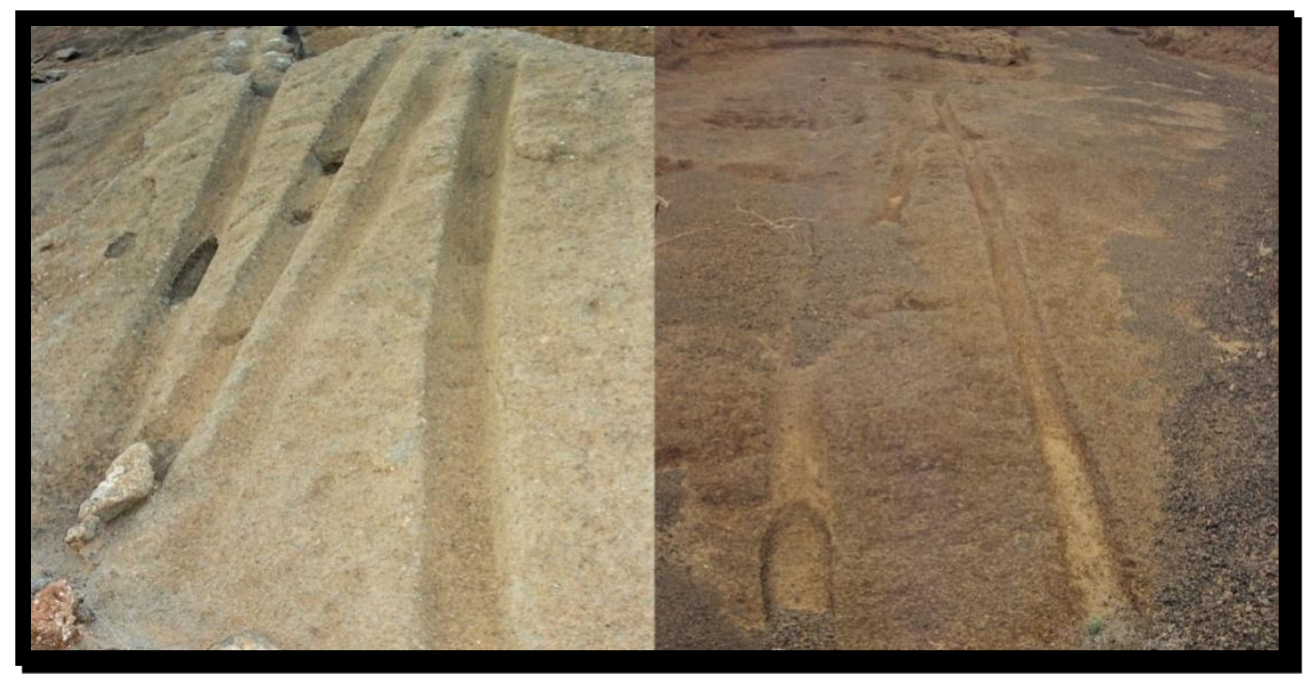

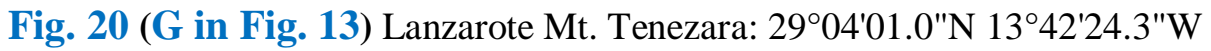




\section{Fuerteventura cart-ruts (?)}

Fuerteventura is geologically (Mapa geologico de España, Arrecife 2004) and culturally related to Lanzarote (Arnaiz-Villena \& Alonso-García 2001;

https://commons.wikimedia.org/wiki/File:Iberian-Guanche_inscriptions.pdf).

Rock ancient Iberian script graffiti have been found throughout both islands, which are more ancient than Lybic-Berber graffiti because they are found must times engraved together in the same rock; Lybic Berber inscriptions are always written above Iberians scripts, Which shows that Iberian writing is more ancient (Arnaiz-Villena \& Alonso García, 2001; Arnaiz-Villena et al. 2015, 2017). These prehistoric Iberian graffiti need an explanation; origins of Iberian script may have been shared between northern Mediterranean and North Africa, both Atlantic and Mediterranean. (Arnaiz-Villena et al. 1999, 2002, 2015, 2017).

Fuerteventura has not been thoroughly searched for cart-ruts, in contrast to Lanzarote Is. However, in Puerto Lajas Beach, close to the capital Puerto del Rosario, structures which may be identified by cart-ruts were also observed (Fig. 21). However, a geological study must discard that this structure has not been made by sea waters.

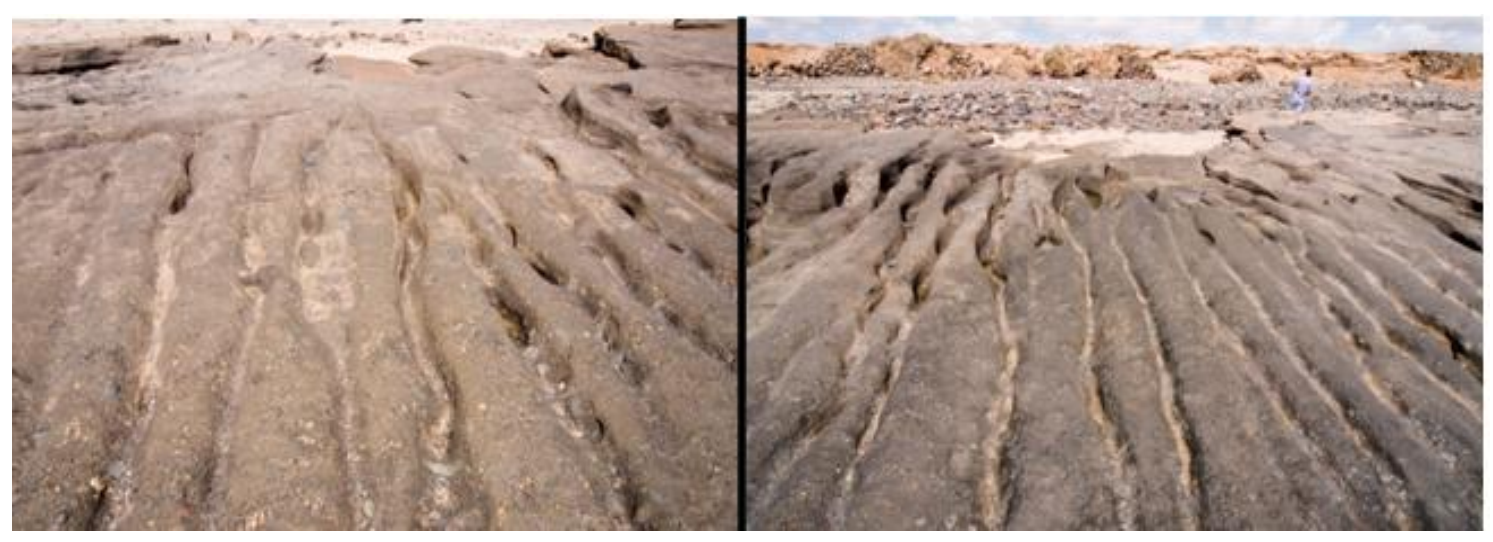

Fig. 21 Cart-ruts (?) at Puerto Lajas Beach, Fuerteventura Is. 28³2'11.7"N 1350'18.0"W.

These structures are covered by water when tide is high. Cart-ruts in Malta and Gozo Islands are described that either come into the sea water or are abruptly cut on high cliffs.

\section{Ceramics}

A wide survey of Fuerteventura and Lanzarote ceramics has not been done. However, two prehistoric vessels shown at Museo Canario (Las Palmas, Gran Canaria Is., Canary 
Islands) have been found to bear lines which may represent cart-ruts like those found in Malta (Fig. 22).

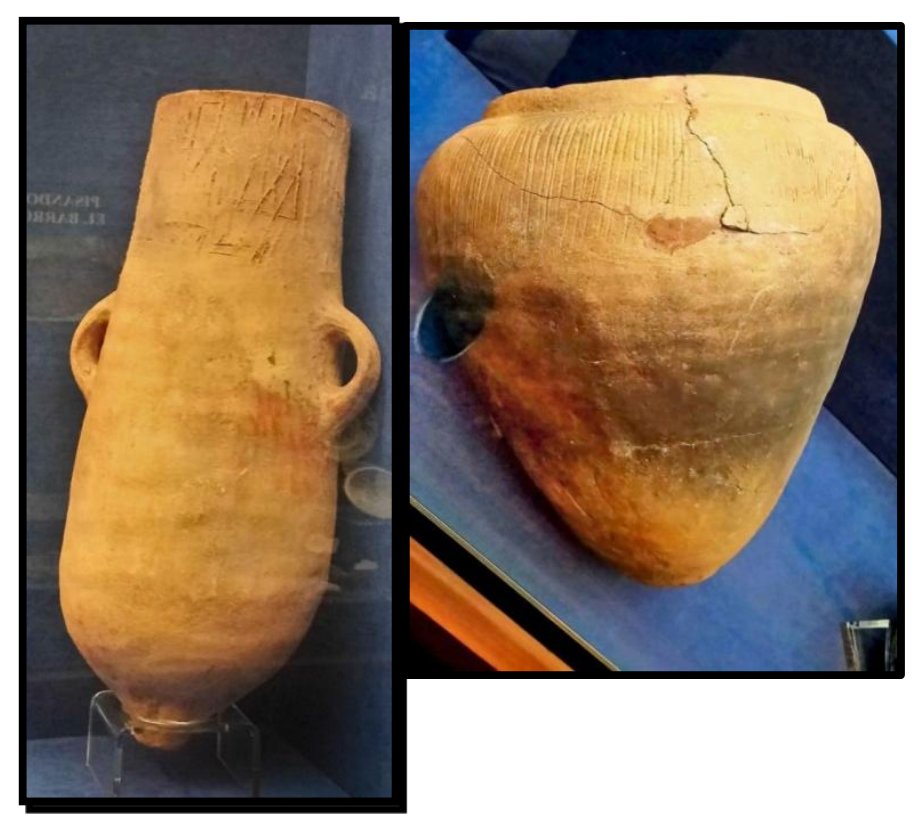

Fig. 22 Prehistoric vessels from Fuerteventura. Museo Canario (Las Palmas, Gran Canaria Is., Canary Islands)

\section{Discussion}

\section{Ceramics: a dating reference to cart-ruts}

This is the first time that an attempt for dating cart-ruts is undertaken by using a possible cart-rut representation in ceramics. Pottering has been shown in Prehistory to be a image of society important facts as shown in Greek pottery and Iberian one (Arribas, 1976). However, pottery studies have usually been underestimated by scholars, because they tried to think in modern terms of pottering adorns being only made for making the particular piece nicer and easier to be sold.

When only exchange and no money economical practices existed, religious, ritual or useful decorative motifs seem to have been favored. Thus, overlooking lines on vessels found in Malta Archipielago where presence of cart-ruts is overwhelming seems to be a mistake. This is the reason because we decided to take into account all available pottery with lines decoration which could represent cart-ruts in Malta. 
Malta and Gozo pottery depicted in Figs. 8, 9, 10, 11 and 12 seem to indicate that a representation of cart-ruts is present. This pottery is dated on the fourth and fifth millennium BC (3,000-4,000 years BC), which would be concordant with Trump studies concluding that Malta cart-ruts belong to Bronze Age at least or even at Temple Period (Trump 1998, 2002, 2008; Bonanno 1993). This would not mean that all described cart-ruts over Mediterranean and Atlantic areas (Bonnici 2007) were built at the same time, only that some of the many Malta ones were built by this time period.

Ceramics cart-rut painting would also mean that were important for the Prehistoric society on every day usefulness, religious or ritual bases (Arribas 1976). In addition, the fact that Lanzarote Is. cart-ruts are constructed on the top or on the slope of mountains further refutes their utility for transport by using carts in the Canary Islands and also in many parts of Malta (Arnaiz-Villena et al. 2018).

\section{Cart-ruts in Malta}

Nowadays, cart-ruts are present all over Malta and Gozo Islands. We analyzed in a previous work three Malta Archipielago cart-ruts sites: at the center of St Gwan City (Malta) (Fig.2.), Ta Cenc (Gozo) (Fig. 6) and Taxxar Gap (St. Paul tat-Targa, Malta) (Fig. 7) (Arnaiz-Villena et al. 2018).

Use of ancient Malta cart-ruts is much debated but picking up water, associated to cisterns, should not be overlooked. Transport is impossible for the rails do not fit with any parallel railway in most of cases (stop abruptly, impossible parallel curves for a vehicle, no sign of human or cattle sleuths in or on the cart-ruts, with horizontal plain angle close to $50^{\circ}-60^{\circ}$ on hill slopes etc).

Dating may be variable but the fact that some cart-ruts on Malta Island go into the water and others are abruptly finished in Gozo cliffs has suggested that some of them were built when sea water was at a different level than present day one (at Last Glacial Maximun about 20,000 thousand years ago, it was about 120 meters lower). Trump (1988, 2002 and 2008) concludes that they may have been constructed at Bronze Age based on different archaeological and historic parameter which he was studying during 30 years in Malta. Conclusions of Conjoint European Union project specific for cart-ruts, only reflects the lack of a broad view of some specialists (Bonnici 2007). This cart-ruts problem must be addressed taking into account not only Archaeology, but also 
Anthropology, Astronomy, Geology and what is known of Prehistory. Thus, the outcome of such a big cart-ruts problem solution in such a big study Bonnichi (2007) is poor and it almost limits to report previous authors conclusions. In our opinion, ancient Bronze Age cart-ruts may represent measurements of space and time (studied by Archaeoastronomy) (Arnaiz-Villena et al. 2018). This was very important for religious and everyday life of Prehistoric Man, as shown in Eurafrica Atlantic coast and different American cultures. The possibility that different cart-ruts in different sites may have been built up in different times and for different purposes is highly possible. However, the finding of Malta Archipielago cart-ruts ceramics which are dated at Bronze Age or earlier would be the first independent objective evidence that Bronze Age cart-ruts existed in Malta.

\section{Cart-ruts in Lanzarote Is.}

Lanzarote Island has been thoroughly inspected by Medina and his group of freelance archaeologists during more than 20 years. Nowadays several extant cart-ruts have been found by them. Exact placement and photographs are shown in Figs. 13, 14, 15, 16, 17 , 18, 19, and 20. None of them seems to have been done by Nature but a detailed geological study is deserved, i.e.: all seem to have been done intentionally by man. Also, they are made on mountains (volcanoes) tops or slopes.

All mountains and cart-ruts are facing East, i.e.: facing Moon, Sun, Canopus and Sirius stars and another stars rising at East horizon. If this cart-ruts have something to do with star observation they are placed in the proper sites, including Mt. Tenezara which is in the West part of the Island but has a wide eastwards view since a preceding big plain permits also a clear eastwards observation.

The word atxano or achano ("year" in Guanche or prehistoric Canarians language, Medina \& Arnaiz-Villena, 2018a, 2018b; Arnaiz-Villena \& Alonso Garcia 2001) has been translated by us (by at $x=a$ hill, axis, stick, ano=shade) by using Basque language. This name suggests that months and seasons could be measured with a hill or stick shade projected at sunrise and/or by Sun along year across cart-ruts. This would be a year or seasonal Sun calendar important for agriculture and other daily religious or ritual life events of Prehistoric Canarians. Other simple instruments i.e.: stick and string or rope could also be used to observe other star rising (including Moon) over horizon during night. Astronomical measurements could be related to some cart-ruts. 
Cart-ruts in one of Mt. Tenezara places (Fig. 20) showing four routs may represent four different seasons. Prehistoric Canary Islanders knew how to establish solstices and equinoxes, both in Lanzarote and Gran Canaria Islands at least. (Medina \& Arnaiz-Villena 2018a, 2018b; Arnaiz-Villena et al. 2018; Barrios-Garcia 2018).

Also, while searching for other archeological artifacts, Medina observed the cart-ruts structure depicted in Fig. 21 at Puerto Lajas, Fuerteventura Is. This structure is seen only when tide is low. It means that if it could be constructed by rock carving men and the time of building would have been when Atlantic Sea waters had a lower level; however, a geological study should be done to discard that these ruts have not been done by Ocean waters. The same phenomenon has been found in Malta in some cartruts which finish under Mediterranean sea waters as pointed out above (Trump 1998, 2002, 2008).

\section{Cart-ruts as space and time markers. Culture}

Present paper describes for the first time independent measurement for dating cart-ruts in dated Malta ceramics show at both Victoria (Gozo) and La Valletta (Malta) Archaelogy Museums. Dating of some of the cart-ruts may be assigned at Bronze or even Temple Malta Age (Bonanno 2017), if it is admitted that ceramic lines are representing cart-ruts, as it seems. Cart-ruts at St. Georges Bay, Birzebbuga and at Mellieha Bay get into the Mediterranean Sea waters at Malta Is. Sea level must have rising at least 2 meters since construction time (Trump 2008). Fuerteventura putative cart-ruts are also found under water on higher tide. This would put back quite a lot these ruts building up time.

Fuerteventura non dated ceramics is shown at Gran Canaria museum (Fig. 22). Their lines which may also represent cart-ruts. In this case, if representation is confirmed, only social, religious importance of putative Fuerteventura cart-ruts would be stressed. Further studies on ceramics and these cart-ruts are deserved by Geology and dating specialized laboratories.

Cart-ruts significance is now not solved. However, this phenomenon has not been studied in a wider context that should include Prehistory, Anthropology, Genetics, Linguistic and many other cultural traits. For instance, Tara (Telde, Canaria Is.) goddess is a fat goddess (Las Palmas Museum, Gran Canaria) and many Malta goddesses statues 
also show fat woman; this is also character of many European prehistoric goddesses (Gimbutas 1991). Other fat goddesses have been found at Canary Islands (Arco-Aguilar \& Navarro-Mederos 1996).

Also, Barrios has put forward (Barrios et al. 2018) that Bentrayga equinoxes observatory at sunrise (Gran Canaria Is) was not as precise as equinoxes calculated at Tara Cave (or Candelaria Virgin Cave, Telde). Observation of equinoxes could be calculated at Gran Canaria Is. Tara cave for being used by all the island religious astronomical/observatory sites i.e.: also at Bentayga Almogaren. The same case could have been occurred at Lanzarote Is., where solstices and equinoxes could have been calculated in one particular place and then several "Queseras"/Cheeseboard or Lunisolar calendars may have been constructed, like that of Zonzamas found and published. At least other four "Quesera"/Cheeseboard have been documented in Lanzarote (Medina \& Arnaiz-Villena 2018a, 2018b; Arnaiz-Villena 2018). Although abundant cart-ruts in Malta may not favour hypothesis of time and/or space measurement possibility of use, perhaps oldest ones had some space/time measurement function together with sticks and string/ropes to measure Sun or stars rising or shades. More recent cart-ruts building may have been used for other purposes. Lanzarote and Fuerteventura cart-ruts dating is not supported by ceramics because dating doesn't exist for ceramics, but cart-ruts social/religious importance is highlighted by ceramics representation (Fig. 22). A multiauthor European Community study on cart-ruts (Bonanno 2005) concludes that are found all over Mediterranean Basin and Europe including Turkey and North Africa and that Malta and Turkey studied cart-ruts belong from Bronze Age. More recent cart-ruts may be possible. No Canary or Azores Islands cart-ruts are studied or named in this work. Our hypothesis is that Lanzarote cart-ruts placement (mountain top or slopes, eastward orientation) suggests that they may be associated to astronomical observatories and also that Prehistoric Canarians could use sticks and ropes for observations: achano means stick shadow and "year" in Prehistoric Canarian language (Barrios-García 2004; Arnaiz-Villena \& Alonso-García 2001; Medina \& Arnaiz-Villena 2018a, 2018b).

Conflicts of Interest: The authors declare no conflict of interest 


\section{Acknowledgements}

We thank University Complutense from Madrid (Spain) for its support and the following colleges who have been important for carrying out present work: Antonio Jesús Montelongo Franquiz, María Antonia Perera Betancor, Máximino Álvarez Pérez, José Manuel Espinel Cejas, Ramón Alfonso Hernández and Orlando Batista Aparicio. Marianne Van der Sluys and Jesús Gonzalez Artabe were (and are) also important for spreading light in Lanzarote archaeology and their help is indebted.

\section{References}

Abela, Commendatore Fra G.F. 1647: Della Descrittione di Malta Isola nel Mare Siciliano con le sue Antichita, de altre Notitie. Ed. Midsea Books (1984), Malta

Arco-Aguilar C. \& Navarro-Mederos J.M. 1996. Los Aborigenes. Ed. L. Romero. La Biblioteca Canaria (Sta Cruz de Tenerife, Is. Canarias, Spain).

Arnaiz-Villena A., Martinez-Laso J., Alonso-Garcia J.1999. Iberia: Population Genetics, Anthropology and Linguistics. Human Biology 71: 725-743.

Arnaiz-Villena A. \& Alonso García J. 2001. Egipcios, Bereberes, Guanches y Vascos. Ed. Visión Libros. (3rd Edition 2011) ACCI. Madrid (Spain).

Arnaiz-Villena A., Gomez-Casado E \& Martinez-Laso J. 2002. Population genetic relationships between Mediterranean populations determined by HLA allele distribution and historic perspective. Tissue Antigens 60: 111-121

Arnaiz-Villena A., Muñiz E., Campos C., Gómez-Casado E., Tomasi S., Martínez Quiles N., Martín-Villa M., Palacio-Gruber J. 2015. Origin of Ancient Canary Islanders (Guanches): presence of Atlantic/Iberian HLA and Y chromosome genes and Ancient Iberian language. Int. J. Mod. Anthrop 8: 67-93.

Arnaiz-Villena A., Carballo A., Juarez I., Muñiz E., Campos C., Tejedor B., MartínVilla M., Palacio-Gruber J. 2017. HLA Genes in Atlantic Celtic populations: Are Celts Iberians? Int. J. Mod. Anthrop 10: 50 - 72.

Arnaiz-Villena A., Medina M., Palacio-Gruber J., Lopez-Nares A., Ruiz-del-Valle V. 2018. Malta and Lanzarote (Canary Islands, Spain) -ruts and Rock Prehistoric Calendar at Zonzamas, Lanzarote-“Quesera”/Cheeseboard-. Int. J. Mod. Anthrop. 11:214-231

Arribas A. 1976. Los Iberos. Ed. Ayma. Barcelona (Spain). 
Barrios García J. 2004. Sistemas de numeración y calendarios de las poblaciones bereberes de Gran Canaria y Tenerife en los siglos XIV-XV. Thesis doctoral. Universidad de La Laguna, Tenerife, Islas Canarias (Spain). http://www.etnomatematica.org/publica/trabajos_doctorado/tenerife.pdf

Barrios Garcia J., Valencia Alfonso V. and Brito Mayor A. 2018. Investigaciones arqueoastronomicas en Gran Canaria. La recamara equinocial de la cueva de la virgen de la Candelaria (Tara, Telde) XXIII Coloquio de Historia Canario Americana. Las Palmas, Gran Canaria. (Islas Canarias, Spain), 1-23.

Bonanno A. 1993.Tarxien Cemetery. Break or Continuity between Temple Period and Bronze Age in Malta? Mediterrâneo 2: 35-47.

Bonnano A. 2017. The Archaeology of Malta and Gozo. Heritage Malta Publishing. Ed. Gutenberg Press Ltd, Malta

Bonnici H. (Project Leader. European Union Multiauthor founded project. Culture 2000 project) 2007. The significance of Cart-Ruts in Ancient Landscapes. Ed. Midsea Books, Malta

Gimbutas M. 1991. Diosas y Dioses de la Vieja Europa. 7000-3500 ac. Ediciones Itsmo. Madrid.Spain.

Magli G. 2016. Archaeoastronomy: introduction to the science of star and stones. Ed. Springuer International Publishing. Switzerland

Mapa geográfico de España. Arrecife, Isla de Lanzarote. 2004. Ed. Instituto geológico y minero de España Madrid.

Medina M. \& Arnaiz-Villena A. 2018a. A lunisolar prehistoric calendar in Lanzarote Island: "LaQuesera"(Cheesboard) from Zonzamas. Int. J. Mod. Anthrop. 21:147-161

Medina M. \&Arnaiz-Villena A. 2018b. The Moon: in Prehistoric Rock Calendar "Quesera" -Cheeseboard- at Lanzarote, Canary Islands, Spain. Int. J. Mod. Anthrop. 2:182-212

Mifsud A., Mifsud S., Agius Sultana C. and Savona Ventura C. 2000. Malta: Echoes of Plato's Island. The Prehistoric Society of Malta, Malta.

Ribeiro N., Joaquinito A., RodriguesAf., Azevedo M.T. 2015. Achaeology and rock art of Macaronesia: New contributions. IV Encontro de Doutorandos e Post-Douorandos Macao.

Ribeiro N., Joaquinito A., Rodrigues AF., Azevedo MT. 2017. Arqueologia e Arte Rupestre na Macronesia, novoscontributos. Techne. 3: 113-124 
Rodrigues AF., Martins NO., Ribeiro N., Joaquinito A. 2015. Early Atlantic Navigation: Pre-Portuguese Presence in the Azores Islands. Archaeological Discovery. 3: 104-113.

Trump D.H. 1998. The Cart Ruts of Malta. Treasures of Malta 4(2), 33-7.

Trump D.H. 2002. Malta, prehistory and Temples. Ed. Midsea Books Ltd., Malta.

Trump D.H. 2008. Cart-Ruts and their impact on Maltese landscape. Ed. Midsea Books Ltd. Malta.

To cite this article:

Antonio Arnaiz-Villena, Marcial Medina, Adrian López-Nares, Julian Rodriguez-Rodriguez, Valentín Ruiz-del-Valle. 2019. Cart-ruts in Lanzarote (Canary Islands,Spain) and Malta: first evidence of dating supported by dated ceramics.

International Journal of Modern Anthropology. 2 (12): 115 - 140

DOI: http://dx.doi.org/10.4314/ijma.v2i12.5

\section{@()) $\Theta \Theta$}

This article, as all articles published in this journal, is under The Creative Commons Attribution: Attribution-NonCommercial-NoDerivatives 4.0 International (CC BY-NC-ND 4.0). https://creativecommons.org/licenses/by-nc-nd/4.0/ 